Creative commons User License: CC BY-NC-ND

Abstracted by: EBSCOhost, Electronic Journals Service (EJS),

Google Scholar, Directory of Open Access Journals (DOAJ),

Journal Seek, Scientific Commons,

Food and Agricultural Organization (FAO), CABI and Scopus
Journal of Agricultural Extension

Vol. 21 (1) February, 2017

ISSN(e): 24086851; ISSN(Print); $1119944 X$

http://journal.aesonnigeria.org

http://www.ajol.info/index.php/jae

Email: editorinchief@aesonnigeria.org

\title{
Sustainability of Marketing Food Crops through the Internet in Lagos, Nigeria
}

http://dx.doi.org/10.4314/jae.v21i1.17

\section{Kolawole, R. A.}

Department of Mass Communication

Ecole Professionnelle Specialisee La Cite Universite, Cotonou, Benin Republic

E-mail: ridwan.kolawole@gmail.com

Phone Number: +2348024203808, +22999359127

\section{Lasisi, M. I.}

Enterprations Limited, Lagos, Nigeria

E-mail: mutiu.iyanda@gmail.com

Phone: +2348062544816

\section{Adeleke, A. O.}

Ministry of Information and Strategy, Osun State, Nigeria

Email: abdulrasheedadeleke@gmail.com

Phone: +2348060085911

\section{Abstract}

The study investigated sustainability of marketing food crops through the Internet in the Lagos metropolis. Survey and in-depth interview were employed for the execution of the study. Purposive sampling technique was used to select 85 questionnaire respondents and communication officer of an online farm produce shopping mall while snowball was adopted for agricultural engineers. The data collected through questionnaire were analysed using descriptive and inferential statistics while the interviews with the communication officer and agricultural engineers were analysed through discursive analysis. The study found that unless there is an improvement, the present organisational factors and available technical infrastructure are not favourable to support the sustainability of the medium $(r=.798, p<.000)$ as a means of marketing farm produce. In essence, the study did not find any clear link between existing information and communication technological infrastructure to the sustainability (marketing) of food crops. Given these, government, telecommunications operators and other Internet service providers should upgrade the broadband connectivity across the country, particularly in the cities.

Key Words: Marketing food crop, internet marketing in Nigeria

\section{Introduction}

Since its emergence, information and communication technology (ICT) of different kinds, processes and methods adopted by farmers and members of various agriculture value chains have revolutionised marketing and distribution stages. The integration of 
Creative commons User License: CC BY-NC-ND

Abstracted by: EBSCOhost, Electronic Journals Service (EJS),

Google Scholar, Directory of Open Access Journals (DOAJ),

Journal Seek, Scientific Commons,

Food and Agricultural Organization (FAO), CABI and Scopus
Journal of Agricultural Extension

Vol. 21 (1) February, 2017

ISSN(e): 24086851; ISSN(Print); $1119944 X$

http://journal.aesonnigeria.org

http://www.ajol.info/index.php/jae

Email: editorinchief@aesonnigeria.org

ICT into agriculture in terms of technologically-developed seeds, fertilizer application and new farming techniques, with each capable of positively impacting the efficiency of farming activities has been seen as lofty idea by stakeholders (Baumüller, 2012; Adeyemo, 2013). Recent advances in technology towards e-agriculture have expanded ICT adoption and application beyond crop cultivation, water management, fertilizer application, pest management, harvesting, post-harvest handling, transportation of food/food products, packaging, food preservation, food processing/value addition, food quality management, food safety, food storage and food marketing to e-marketing and shopping of both food and cash crops (Baumüller, 2012).

Despite the advantages, technological and organisational cultures have been found as the main barriers to effective implementation of ICT related programmes in the business world (Purnomo and Lee, 2010). Therefore, concerned stakeholders have made various efforts towards the development of strategies and techniques to solve identified obstacles towards the adoption of technologies such as the Internet and by extension ecommerce for marketing and purchasing of agricultural commodities.

This study assessed continued success of communicating food crops through the Internet and by extension e-commerce (virtual retail stores). This becomes imperative considering its adoption for marketing and purchasing of varied non-consumable goods and recently farm products in Lagos, a large commercial centre in Nigeria. Up to this point, none of the available studies has exclusively focused on the sustainability of this medium. This is the gap in knowledge which the current study aims to fill. Success or otherwise of technology usage has been premised on many theoretical propositions and experience.

Theoretically, Unified Theory of Acceptance and Use of Technology (UTAUT) has made us understand that users/consumers (in this case, Lagos residents) are likely to make purchase of food crop through the medium due to availability of certain organisational factors (emphasis added) and technical infrastructure, which support its effective use. On the other hand, they might not use it if they feel that there are emotional factors after its use (Venkatesh, Morris, Davis and Davis, 2003). Uses and Gratifications theory adds that as long as food crops are marketed through the Internet and Lagos residents continue to purchase their preferred commodities, the medium will remain important to them. It predicts that the benefits both the marketers and residents will derive from the medium will be influenced by social institutions, circumstances, personal traits, needs and values (Pearce, 2009). Supporting uses and gratification theory's prediction, dependency theory identifies individual specific needs and motives, social conditions 
Creative commons User License: CC BY-NC-ND

Abstracted by: EBSCOhost, Electronic Journals Service (EJS),

Google Scholar, Directory of Open Access Journals (DOAJ),

Journal Seek, Scientific Commons,

Food and Agricultural Organization (FAO), CABI and Scopus
Journal of Agricultural Extension

Vol. 21 (1) February, 2017

ISSN(e): 24086851; ISSN(Print); 1119944X

http://journal.aesonnigeria.org

http://www.ajol.info/index.php/jae

Email: editorinchief@aesonnigeria.org

outside of the individual's control, and life attributes as factors capable of increasing or decreasing marketers and consumers' dependence on the medium (Pearce, 2009). Based on these propositions and constructs, the following research questions emerges:

i. what are the benefits of marketing and purchasing food crops through the Internet in Lagos State?

ii. what are the push and pull factors towards the sustainability of marketing and buying food crops through the Internet in the state?

Within this study, we considered push as discouraging elements likely to dissuade consumers from buying their preferred food crops through the medium, while pull was seen as facilitating conditions.

\section{Objectives of the Study}

Specifically, this study was designed to:

i. examine benefits of marketing and purchasing food crops through the Internet by Lagos residents.

ii. examine those factors that either encourage or discourage the sustainability of marketing and buying food crops through the Internet in Lagos State.

For further inferences, we hypothesized that the motivating organisational factors and available technical infrastructure will contribute to the sustainability of the medium more than discouraging organisational factors and available technical infrastructure in the state or otherwise. With this, we hope to reveal specific factor towards the sustainability and non-sustainability of the medium in farm products purchasing. Categorically, the hypothesis is stated thus:

\section{Hypothesis}

$\mathrm{H}_{1}$ : Motivating organisational factors will contribute to the sustainability of the medium more than discouraging organisational factors and available technical infrastructure

\section{E-Agriculture: Marketing and Purchasing Patterns}

Like producers and marketers of other consumable goods, farmers and agricultural commodities marketers have also realized that technology needs to be incorporated into their ways of making farm produce available to consumers, especially in urban areas through e-commerce and other business-assisted new media. Presence of ICTs in today's business environment has made marketers of farm products to adopt many marketing communication methods with the Internet as medium of disseminating information and explaining unique features of their produce to the consumers. In the past, farmers and consumers met at specific locations in towns and cities where both had the opportunity of fulfilling their selling and buying needs. The advent of "the Internet of Thing" has however changed the patterns through which marketers and 
Creative commons User License: CC BY-NC-ND

Abstracted by: EBSCOhost, Electronic Journals Service (EJS),

Google Scholar, Directory of Open Access Journals (DOAJ),

Journal Seek, Scientific Commons,

Food and Agricultural Organization (FAO), CABI and Scopus
Journal of Agricultural Extension

Vol. 21 (1) February, 2017

ISSN(e): 24086851; ISSN(Print); 1119944X

http://journal.aesonnigeria.org

http://www.ajol.info/index.php/jae

Email: editorinchief@aesonnigeria.org

consumers meet their marketing and buying needs. Online retail channel has been added to the traditional distribution chain. Many online food retailers have evolved in the last decade both in developing and in developed countries. They have emerged as highly technological businesses that help consumers in making use of different technologies. With the aid of the Internet, the activities of the online retail of food crops have been made easy such that prospective customers are exposed to the varieties via the online platform supported by the internet. The internet is perceived to be a fast medium and a resourceful instrument which is readily available for use (Aromolaran, Alarima, Akerele, Oyekunle and Leramo, 2016). This usefulness and pervasiveness therefore presents the Internet as a veritable tool in online marketing.

Across the world, online retail outlets are facilitating marketing and distribution of farm products to households, restaurants, and institutions by developing scale efficiency and improving available technical infrastructure (Matson, Sullins and Cook, 2013). Post (2012) referring to Thilmany, et al. notes that consumers and growers (farmers) are not left out in the adoption of the Internet use. They are purchasing more and selling more produce using their own websites and other online applications, allowing access to a larger customer base. As consumers develop interest in buying food and cash crops through online shopping mall, scholars have started investigating factors that affect their buying decisions (Ranadive, 2015). If sellers and consumers' intention to make use of the Internet for marketing or communicating produce' benefits are increasing every day, how sustainable is this online transaction in a busy city like Lagos, Nigeria. Consumers are specifically expected to make sustainable choices, which cannot be achieved through communication alone. They need technologies to enable them to act appropriately. In other words, sellers need to supply viable products while consumers need to buy responsibly without compromising the ability of doing so in the future (Futerra and Montillaud-Joyel, 2005; Sustainable Food Policy, 2016).

\section{Benefits and Impacts of Marketing and Purchasing through the Internet}

Many studies have been conducted on the benefits and impacts which relevant stakeholders have derived and still been derived from retail marketing outlets, most importantly the traditional outlet. It has been found that local farmers in rural areas have benefited immensely from selling their fresh products through direct markets while consumers have had the opportunity of making choice from different available products (Woodside and Trappey, 1992 in Chen and Tan, 2004; Kankanamge, 2012). To the marketers, Fox and Ernst (2009) argue that the internet technologies remain basic effective strategy for potential benefits for better marketing. In their study, Chen and Tan (2004) identified product offerings, information richness, usability of storefront, 
Creative commons User License: CC BY-NC-ND

Abstracted by: EBSCOhost, Electronic Journals Service (EJS),

Google Scholar, Directory of Open Access Journals (DOAJ),

Journal Seek, Scientific Commons,

Food and Agricultural Organization (FAO), CABI and Scopus
Journal of Agricultural Extension

Vol. 21 (1) February, 2017

ISSN(e): 24086851; ISSN(Print); $1119944 X$

http://journal.aesonnigeria.org

http://www.ajol.info/index.php/jae

Email: editorinchief@aesonnigeria.org

perceived trust and perceived service quality as factors that have impacted acceptability of virtual store over the years. The most prominent factors include attitude, subjective norms and perceived behavioural control (Ranadive, 2015). According to Chen and Tan (2004:74) "consumers have realised the benefits of shopping online, but at the same time been impeded by factors such as security and privacy concerns, download time and unfamiliarity with the medium." A recent study in Nigeria shows that online consumers were afraid of buying through the online shopping malls due to perceived financial risk, product performance, social, psychological and time or convenience loss (Olusoji, Ogunkoya, Lasisi and Elumah, 2015). Another Study has also suggested that price, convenience, product information return policy and delivery risk are significant to re-purchase in e-stores (Khan, Liang and Shahzad, 2015). Li, Fu and Li (2010) have earlier found a positive relationship between perceived usefulness and adoption of mobile commerce while cost is also adjudged as the main criterion for e-commerce adoption. Investigating economic benefits of Market Maker, an online retail outlet, Kankanamge (2012) discovered that consumers' familiarity with the platform in terms of their purchase increased the share of total sales of vegetables while Internet speed was found to be a significant barrier.

It is imperative to understand that the Internet as a new medium has been helpful over the years for marketing of all categories of goods both in developed and developing countries. In US for instance, Kankanamge (2012) points out that ebay.com, Amazon.com, National Food Industry Market Maker and social media are commonly used. Presently, many online shopping sites are thriving in Nigeria, servicing thousands of buyers every week. Some of these online shopping sites include Jumia.com, Dealdey.com, Buynownow.com and Konga.com. Many of these sites make the transaction process so easy that buyers forget about the open market (Ciuci Consulting, 2013). Having realized that many Nigerians, especially the working class people and affluent ones in the cities such as Lagos, Abuja, Port-Harcourt are finding it difficult daily to purchase food crops and other farm produce for consumption due to a number of factors (like lack of time to make purchase at local markets and transportation problem), many online food recipes retail outlets have emerged; creating enabling environment for different categories of people for the purchase of varied food crops. Farm Direct, Foodstantly and Forfoodonly are some of the outlets that cater for the needs of over 20 million people in Lagos State through their strategic collaboration and alliance with conventional markets, namely; Mile 12 (then), Orinoco, Ajah and Mushin markets, where farm produce are sold. They proposed that it would be convenient for the consumers to buy food by averting traffic, bad weather, distance, time constraint, among others. 
Creative commons User License: CC BY-NC-ND

Abstracted by: EBSCOhost, Electronic Journals Service (EJS),

Google Scholar, Directory of Open Access Journals (DOAJ),

Journal Seek, Scientific Commons,

Food and Agricultural Organization (FAO), CABI and Scopus
Journal of Agricultural Extension

Vol. 21 (1) February, 2017

ISSN(e): 24086851; ISSN(Print); $1119944 X$

http://journal.aesonnigeria.org

http://www.ajol.info/index.php/jae

Email: editorinchief@aesonnigeria.org

\section{Methodology}

Quantitative and qualitative approaches to research were chosen for the attainment of the study's objectives. Survey was specifically chosen as research design. Consumers of various food crops, operators of online food crops retail outlets, and experts from the academia (Agricultural Science and Engineering/ICT) residing in Lagos constituted population of the study. Purposive, and snowball sampling procedures were employed for the selection of samples from the population. Eighty-five consumers, two academics and a representative of one of the online operators were, therefore, purposively selected. Out of the selected consumers, 14 consumers filled the questionnaire through the adopted online platform while 71 did it through face-to-face approach. For the indepth interview, structured written interview guide (SWIG) was used as the research instrument for data collection from agricultural experts. This instrument contained four semi-structured questions. In addition, telephone interview aided by semi-structured interview guide was conducted for the online communication officer of an online farm produce shopping mall (Forfoodonly).

The questionnaire was the main research instrument for the collection of data. Three questions were formulated as control questions, which resulted into 22 items. Respondents were asked to rank the items through 4-Likert type scale of 'very great extent, great extent, little extent and no extent'. Specifically, the questionnaire contained items that probed factors that motivated consumers to purchase their preferred food crops from the online shopping mall and factors that would discourage them from the future purchase. The selected consumers were also asked to specify their demographic details. These included gender, monthly income and employment types. The instrument was administered through an online survey collection platform (SurveyMonkey) and one-on-one means within the study's setting. Suffice to note that, researchers ensured that only consumers who have purchased food crop through the online shopping malls situated in Lagos state participated in the study. This was done through a control questionnaire item added to the instrument.

Data were analysed quantitatively and qualitatively. Frequency count percentage, t-test and chi-square were used for the quantitative analysis while emerging themes and discursive analysis method was adopted for the qualitative aspect of the study. Frequency count, percentage and t-test were specifically adopted for the analysis of items formulated for benefits and factors on the questionnaire. Percentage was also used for the description of respondents' demographic details. Chi-square was used to test the relationship between motivating organisational factors and available technical infrastructure. 
Creative commons User License: CC BY-NC-ND

Abstracted by: EBSCOhost, Electronic Journals Service (EJS),

Google Scholar, Directory of Open Access Journals (DOAJ),

Journal Seek, Scientific Commons,

Food and Agricultural Organization (FAO), CABI and Scopus
Journal of Agricultural Extension

Vol. 21 (1) February, 2017 ISSN(e): 24086851; ISSN(Print); $1119944 X$

http://journal.aesonnigeria.org

http://www.ajol.info/index.php/jae

Email: editorinchief@aesonnigeria.org

To make the inferences, items formulated for pull and push factors were further divided into organisational factors and availability of technical infrastructure in relation with the specific proposition of Unified Theory of Acceptance and Use of Technology. Responses of the selected consumers were coded using 4 for Very Great Extent, 3 for Great Extent, 2 for Little Extent and 1 for No Extent. Validity and reliability of the questionnaire was determined through Alpha Cronbach. Scales for the six items on the questionnaire for the benefits were found valid and reliable at .867, 9 items for the motivating factors were valid and reliable at .915 and 6 items of discouraging factors were also valid and reliable at .899. These were above the .69 acceptable thresholds of calculating and determining validity and reliability of items in survey design. Thus, they were found dependable for the collection of necessary data towards valid discussion.

\section{Results and Discussion}

A significant number of the sampled respondents were male $(57=67.1 \%)$, followed by female $(28=33 \%)$. Over $45 \%$ of them were earning more than N55, 000 per month. It was also discovered that $30.6 \%$ and $20 \%$ of the respondents were being paid between 25,000 to 34,000 and 45,000 to 54,000 respectively. The data gathered for their employment type status revealed that over $78 \%$ were working within the private sector while $21.2 \%$ were civil servants. The majority $(83=97.6 \%)$ obtained higher educational qualifications.

\section{Benefits of Marketing and Purchasing Food Crop through the Internet}

Figure 1 shows that, out of the six benefits, the majority of the respondents identified convenience, cheaper price, timely delivery of the ordered crops, freshness of the crops, varieties and, easy and personalized experience devised as encouraging factors. Over $56 \%$ of the sampled respondents were of the view that they had opportunities of choosing a different number of food crops from the online shopping malls they had patronized. This they consider as another factor that may keep them patronising the medium. Forty-three respondents representing $50.5 \%$ believed that the medium is easier to operate and that their experiences have been personalized. By extension, the interviewees agreed on a number of benefits derivable from online purchase of farm produce. The customers explained that they will concentrate more on their jobs, reduce traffic congestions on the road and at the market and at the same time order their needed farm produce. In addition, the agricultural experts posited that the online platform will open up more job opportunities for the prospective online operators. These findings are within one of the propositions of Uses and Gratifications theory. It predicts that the benefits both the marketers and residents will derive from the medium will be 
Creative commons User License: CC BY-NC-ND

Abstracted by: EBSCOhost, Electronic Journals Service (EJS),

Google Scholar, Directory of Open Access Journals (DOAJ),

Journal Seek, Scientific Commons,

Food and Agricultural Organization (FAO), CABI and Scopus
Journal of Agricultural Extension

Vol. 21 (1) February, 2017

ISSN(e): 24086851; ISSN(Print); $1119944 X$

http://journal.aesonnigeria.org

http://www.ajol.info/index.php/jae

Email: editorinchief@aesonnigeria.org

influenced by social institutions, circumstances, personal traits, needs and values (Pearce, 2009).

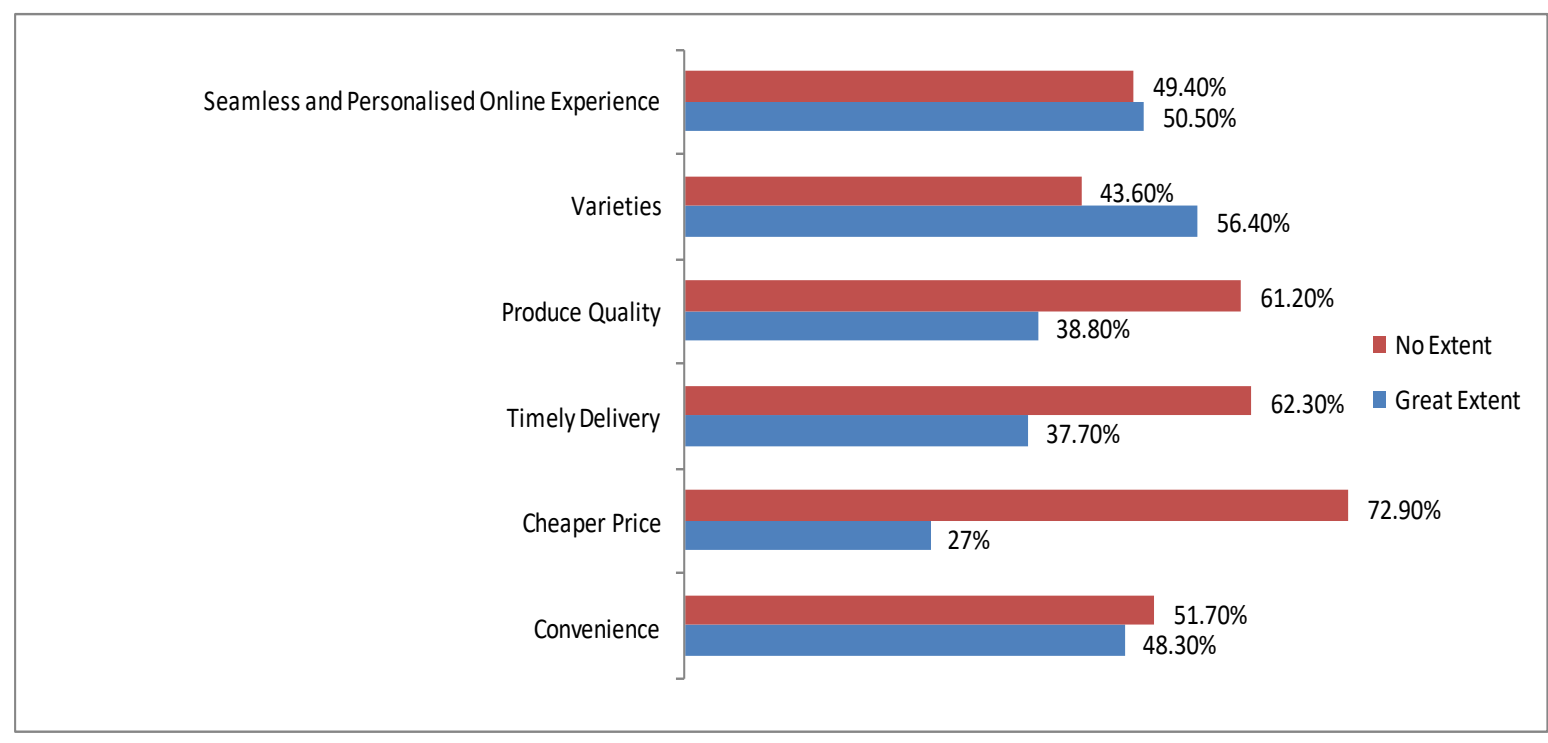

Figure 1: Benefits and encouraging factors of purchasing food crop through the Internet

\section{Encouraging Factors}

Some respondents were of the view that easy ordering and payment $(M=2.65$, $\mathrm{SD}=.948$ ) was the factor motivating them the most in purchasing their preferred food crops, (Table 1). The Table further established that sampled consumers believed that marketers will deliver crops ordered to them $(M=2.56, S D=1.052)$ and had opportunity of choosing different kinds of crop $(M=2.49, S D=.946)$. It was also gathered that consumers have benefited from the medium by receiving adequate information on advertised crops $(M=2.45, S D=1.018)$. Interviewees were unanimous on the fact that products' freshness accounts for customers continued patronage of online shopping. The implication of these results is that organisational factors would continue to motivate consumers in buying food crops through the medium than available technical infrastructure.

Supporting the findings from survey, the interviewees also agreed with the fact that availability of varieties of food crops encouraged the buyers. The communication officer of Forfoodonly contended that her online shopping mall is one-stop shop where different food crops are sold to customers. She maintained that instead of the customers to go to 
Creative commons User License: CC BY-NC-ND

Abstracted by: EBSCOhost, Electronic Journals Service (EJS),

Google Scholar, Directory of Open Access Journals (DOAJ),

Journal Seek, Scientific Commons,

Food and Agricultural Organization (FAO), CABI and Scopus
Journal of Agricultural Extension

Vol. 21 (1) February, 2017

ISSN(e): 24086851; ISSN(Print); $1119944 X$

http://journal.aesonnigeria.org

http://www.ajol.info/index.php/jae

the conventional market and move from one place to the other to buy different food crops, they can order for all these crops within minutes. According to her, the userfriendly and easy online navigation would aide ordering and payment of products bought by customers online. To the experts, online purchase reduces the problems involved in buying from conventional market. These include traffic congestion and busy schedules of the customers in their office. The experts also noted that "functional" and "effective" internet infrastructure will encourage the buyers of farm produce while epileptic internet supply will discourage the online buyers.

Table 1: Factors that encouraged respondents to buy farm produce online

\begin{tabular}{llll}
\hline Factor & Mean & Standard & $\mathbf{t}$ \\
\hline & & Deviation & \\
Easy Ordering and Payment & $\mathbf{2 . 6 5}$ & $\mathbf{9 4 8}$ & $\mathbf{- 3 . 4 3 4}$ \\
Trust in delivery & $\mathbf{2 . 5 6}$ & $\mathbf{1 . 0 5 2}$ & $\mathbf{- 3 . 8 1 6}$ \\
Varieties & $\mathbf{2 . 4 9}$ & $\mathbf{. 9 4 6}$ & $\mathbf{- 4 . 9 2 8}$ \\
Adequate Produce' Benefits & $\mathbf{2 . 4 5}$ & $\mathbf{1 . 0 1 8}$ & $\mathbf{- 5 . 0 0 9}$ \\
Information & & & \\
Timely Delivery & 2.36 & .962 & -6.090 \\
Crops' Freshness & 2.29 & .998 & -6.601 \\
Stable Internet Connection & 2.29 & .998 & -6.522 \\
Affordability & 2.27 & 1.005 & -6.694 \\
Absence of geographical boundary & 2.16 & .884 & -8.708 \\
& & & \\
\hline
\end{tabular}

\section{Discouraging Factors}

According to the data presented in Table 2, high price $(M=2.82, S D=1.093)$, delay in delivering ordered crops $(\mathrm{M}=2.82, \mathrm{SD}=1.080)$, difficult ordering and payment platform navigation $(M=2.76, S D=1.080)$, unsecure electronic payment and online identity theft $(M=2.78, S D=1.117)$ are the factors that would lead to non-purchase of food crops through online shopping malls. 
Creative commons User License: CC BY-NC-ND

Abstracted by: EBSCOhost, Electronic Journals Service (EJS),

Google Scholar, Directory of Open Access Journals (DOAJ),

Journal Seek, Scientific Commons,

Food and Agricultural Organization (FAO), CABI and Scopus
Journal of Agricultural Extension

Vol. 21 (1) February, 2017

ISSN(e): 24086851; ISSN(Print); $1119944 X$

http://journal.aesonnigeria.org

http://www.ajol.info/index.php/jae

Email: editorinchief@aesonnigeria.org

Table 2: Factors that discourage respondents from buying farm produce online

\begin{tabular}{|c|c|c|c|}
\hline Factor & Mean & $\begin{array}{l}\text { Standard } \\
\text { Deviation }\end{array}$ & $t$ \\
\hline Higher price & 2.82 & 1.093 & -1.489 \\
\hline Delay in delivery & 2.82 & 1.080 & -.904 \\
\hline $\begin{array}{l}\text { Difficulty in navigating through the } \\
\text { marketers' ordering and payment } \\
\text { platforms }\end{array}$ & 2.76 & 1.080 & -2.153 \\
\hline $\begin{array}{l}\text { Insecurity of electronic payment } \\
\text { platform }\end{array}$ & 2.69 & 1.080 & -2.610 \\
\hline Online identity theft & 2.78 & 1.117 & -1.845 \\
\hline Poor customer relationship & 2.54 & 1.030 & -4.107 \\
\hline
\end{tabular}

High price and delay in delivery were the most significant factors. It also implies that organisational factors are sufficient enough to discourage consumers from purchasing food crops through online shopping malls. The findings from the survey were corroborated by one of the interviewees, Forfoodonly's Communications Manager, who disclosed that some individuals did not subscribe to online shopping for agricultural products because of perceived difficulty in navigating through the marketers' ordering and payment platforms. She said, "Some online marketing platforms are not userfriendly and this scares customers away from such sites. E-commerce platform are characterised with complex processes which may take extra time for the customers to understand. Understandably, many online users are in haste to get what they want especially that the internet stability is not always assured." She added that those who buy small quantity of product "will not be motivated to buy online because my company charges N1, 500 for any transaction. I believe it would not be economical for someone who is buying product worth N500 to shop for it online and have it delivered for N1, 500". As indicated by the respondents, the interviewees also aligned with the fact that delay in delivery will discourage the customers.

\section{Relationship Between Organisation Factors and Sustainability of Medium}

Correlation analysis indicated that discouraging organisational factors and (poor state of the) available technical infrastructure will lead to the non-sustainability of the medium $(r=.798, p<.000)$ (Table 3). 
Creative commons User License: CC BY-NC-ND

Abstracted by: EBSCOhost, Electronic Journals Service (EJS),

Google Scholar, Directory of Open Access Journals (DOAJ),

Journal Seek, Scientific Commons,

Food and Agricultural Organization (FAO), CABI and Scopus
Journal of Agricultural Extension

Vol. 21 (1) February, 2017

ISSN(e): 24086851; ISSN(Print); $1119944 X$

http://journal.aesonnigeria.org

http://www.ajol.info/index.php/jae

Email: editorinchief@aesonnigeria.org

Table 3: Relationship between organizational factors and infrastructure

\begin{tabular}{ll}
\hline Correlating Factors & $\begin{array}{l}\text { Pearson } \\
\text { Correlation }\end{array}$ \\
\hline $\begin{array}{l}\text { Discouraging Organisational Factors and Discouraging } \\
\text { technical infrastructure }\end{array}$ & $.789^{\star *}$ \\
& \\
$\begin{array}{l}\text { Organisational Factors and } \\
\text { Motivating Technical Infrastructure }\end{array}$ &. $\mathbf{8 3 0 ^ { * * }}$ \\
\hline
\end{tabular}

- $\mathrm{P} \leq 0.05$

Again the data show that motivating organisational factors and available motivating technical infrastructure will lead to the sustainability of the medium $(r=.830, p<.000)$.

Generally, high price, delay in delivering ordered crops, difficult ordering and payment platform navigation, unsecure electronic payment and online identity theft were the core push factors that would lead to non-purchase of food crops through the medium. Easy ordering and payment, trust in the delivery of crops ordered and opportunity of choosing different kinds of crop, adequate information on the produce, good internet connection, user-friendly designed e-commerce platform and time flexibility are the main pull factors that would ensure the sustainability of buying through the medium. These findings agree with a number of previous findings. For the push factors, findings of Olusoji et al (2015) and Khan et al., (2015) align with the current findings. They found perceived financial risk, less product performance, delivery risk, social, psychological and time or convenience loss as factors significant to re-purchase in virtual stores.

Organisational factors are significant enough to motivate or discourage consumers towards continuous purchase of their preferred food crops through online shopping malls than existing technical infrastructure. Thus, the sustainability of purchasing food crops through online shopping malls remains doubtful in Lagos state from the identified underlying organisational conditions.

Present pull factors are in consonance with Chen and Tan's findings (2004). The scholars found varied product offerings, information richness, usability of storefront, perceived trust and perceived service quality as factors that have impacted acceptance of virtual store in their study setting. Discouraging organisational factors and available technical infrastructure will lead to the non-sustainability of the medium while motivating organisational factors and available motivating technical infrastructure will lead to the sustainability of the medium. In addition, discouraging organisational factors have the high propensity of contributing to the non-sustainability of the medium more than 
Creative commons User License: CC BY-NC-ND

Abstracted by: EBSCOhost, Electronic Journals Service (EJS),

Google Scholar, Directory of Open Access Journals (DOAJ),

Journal Seek, Scientific Commons,

Food and Agricultural Organization (FAO), CABI and Scopus
Journal of Agricultural Extension

Vol. 21 (1) February, 2017

ISSN(e): 24086851; ISSN(Print); 1119944X

http://journal.aesonnigeria.org

http://www.ajol.info/index.php/jae

Email: editorinchief@aesonnigeria.org

discouraging available technical infrastructure. These findings are in line with Unified Theory of Acceptance and Use of Technology's theory prediction that availability of certain factors and technical infrastructure go in a long way of determining effective

usage of technological application by people (Venkatesh et al., 2003). It was also further discovered that motivating organisational factors and available technical infrastructure will encourage continued purchase of food crops through the medium than available motivating technical infrastructure. These findings in relation with dependency theory's prediction have established that individual specific needs, motives and life attributes are capable of increasing or decreasing consumers' dependencies on the ecommerce/virtual stores (Pearce, 2009).

\section{Conclusion and Recommendations}

The study did not find any clear link between existing information and communication technological infrastructure to the sustainability (marketing) of food crops. Given these, government, telecommunications operators and other Internet service providers should upgrade the broadband connectivity across the country, particularly in the cities. In order to sustain the marketing of food crops through virtual stores, the online shopping malls should make their website user-friendly. That is, they should be self-educating for the customers and simple to access by the prospective buyers. In addition,

Government and telecommunications operators and other Internet service providers should intensify their efforts on the upgrade of broadband connectivity across the country, particularly in cities. Nigerian Communications Commission and other relevant agencies should ensure full implementation of existing Internet security laws. For flexible mobility and time constraint, consumers would need to continue buying their preferred food crops through virtual stores in the populated cities such as Lagos. The present number of online stores for food crops in Lagos is not sufficient to cater for the needs of the numerous potential and existing customers who live in different distant parts of the city.

\section{References}

Adeyemo, A. B., (2013) 'An e-farming framework for sustainable agricultural development in Nigeria' Journal of Internet and Information System, Vol. 3

(1) Pp.1-9

Aromolaran, A. K.; Alarima, C. I.; Akerele, D.; Oyekunle, O. and Leramo, G. A. (2016) Use of Internet for Innovation Management by Extension Agents in Oyo State. Journal of Agricultural Extension. Vol. 20 (1). Pp 960-106

Baumüller, H., (2012) 'Facilitating agricultural technology adoption among the poor: The role of Service delivery through mobile phones.' Working Paper Series 93, Center for 
Creative commons User License: CC BY-NC-ND

Abstracted by: EBSCOhost, Electronic Journals Service (EJS),

Google Scholar, Directory of Open Access Journals (DOAJ),

Journal Seek, Scientific Commons,

Food and Agricultural Organization (FAO), CABI and Scopus
Journal of Agricultural Extension

Vol. 21 (1) February, 2017

ISSN(e): 24086851; ISSN(Print); 1119944X

http://journal.aesonnigeria.org

http://www.ajol.info/index.php/jae

Email: editorinchief@aesonnigeria.org

Development Research, University of Bonn. Accessed on

http://www.zef.de/uploads/tx_zefportal/Publications/wp93.pdf

Chen, L., and Tan, J., (2004) 'Technology Adaptation in E-commerce: Key

Determinants

of Virtual Stores Acceptance' European Management Journal Vol. 1, Pp. 74-86, Access on http://0- dx.doi.org.pugwash.lib.warwick.ac.uk/10.1016/j.emj doi:10.1016/j.emj

Ciuci Consulting (2013) "Prospects and Challenges of Online Retail in Nigeria" Accessed on http://www.ciuci.us/wp-content/uploads/2013/11/Prospect-

Kankanamge, S.K., (2012) 'Marketing Channels and Internet Technology Used by Specialty Crop Farmers' A Thesis Submitted to the Graduate Faculty of the Louisiana State University and Agricultural and Mechanical College, The Department of Agricultural Economics and Agribusiness

Khan, S.A., Liang, Y. and Shahzad, S. (2015) 'An Empirical Study of Perceived Factors Affecting Customer Satisfaction to Re-Purchase Intention in Online Stores in China.' Journal of Service Science and Management, Vol. 8 Pp. 291-305. http://dx.doi.org/10.4236/jssm.2015.83032

$\mathrm{Li}, \mathrm{Y}$., Fu, Z.T., and Li, H., (2007) 'Evaluating factors affecting the adoption of mobile commerce in agriculture: An empirical study' Pp-1213-1218New Zealand Journal of Agricultural Research. Accessed on http://dx.doi.org/10.1080/00288230709510404

Matson, J., Sullins, M., and Cook, C., (2013) 'The Role of Food Hubs in Local Food Marketing' United States Department of Agriculture, Rural Development. Service Report 73

Olusoji, J.G., Ogunkoya, O.A., Lasisi, J.A., and Elumah, L.O., (2015) 'Risk and Trust in Online Shopping: Experience from Nigeria' International Journal of African and Asian Studies Vol. $11 \mathrm{Pp}-71-77$

Pearce, W., (2009) 'Dependency Theory' in Stephen W. Littlejohn, Karen A. Foss Encyclopedia of Communication Theory California: Sage Publications

Post, E., (2012) 'Social Media Tool for Farm Product Marketing' NCAT Agriculture Specialist Accessed on www.attra.ncat.org

Purnomo, S.H., and Lee, Y., (2011) 'An Assessment of Readiness and Barriers towards ICT Programme Implementation: Perceptions of Agricultural Extension Officers in Indonesia' International Journal of Education and Development using Information and Communication Technology, Vol. 6 (3). Pp. 19-36.

Ranadive, A., (2015) 'An Empirical Study on the Online Grocery Shopping Intentions of Consumers in Vadodara City' International Journal of Management and Social Sciences Research Volume 4, (3). Pp8-14 
Creative commons User License: CC BY-NC-ND

Abstracted by: EBSCOhost, Electronic Journals Service (EJS), Google Scholar, Directory of Open Access Journals (DOAJ), Journal Seek, Scientific Commons,

Food and Agricultural Organization (FAO), CABI and Scopus

Sustainable Food Policy (2016) 'A Guide to Developing a Sustainable Food Purchasing Policy' Accessed on www.sustainablefoodpolicy.org

Venkatesh, V., M. G. Morris, G. B. Davis and F. D. Davis (2003) ‘User Acceptance of
Information Technology: Toward a Unified View’, MIS Quarterly Vol. 27 (3). Pp.

Venkatesh, V., M. G. Morris, G. B. Davis and F. D. Davis (2003) ‘User Acceptance of
Information Technology: Toward a Unified View’, MIS Quarterly Vol. 27 (3). Pp. $425-$ 478.
Vol. 21 (1) February, 2017

ISSN(e): 24086851; ISSN(Print); 1119944X

http://journal.aesonnigeria.org

http://www.ajol.info/index.php/iae
Journal of Agricultural Extension 